\title{
Research Article \\ Antibiotic-Resistant Profiles of Bacteria Isolated from Cesarean and Surgical Patients from Kasese District Hospitals Western Uganda
}

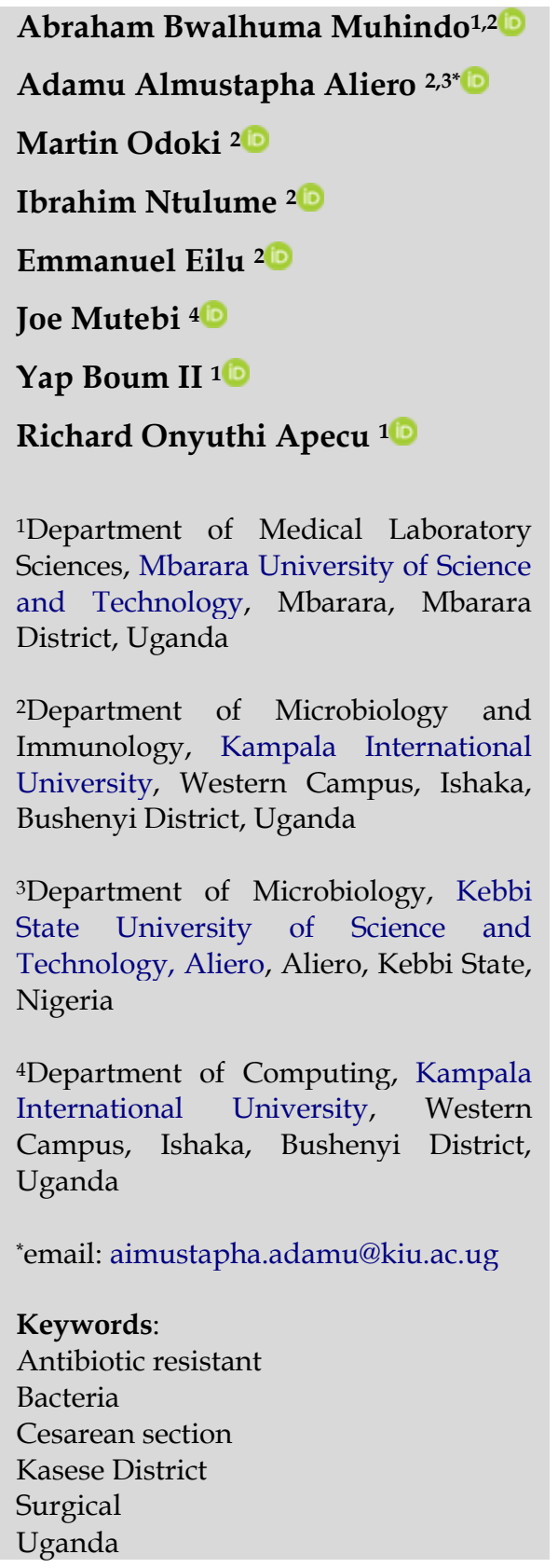

\begin{abstract}
Surgical site infections (SSIs) are challenging to treat and often associated with much higher extended stays, morbidity, and mortality, higher treatment costs, especially when the causative agent is multidrug resistance (MDR). This study was designed to determine the prevalence of nosocomial infections and susceptibility profiles of bacteria isolated from Cesarean section (C-section) and surgical patients from Kasese District Hospitals in Western Uganda. A descriptive cross-sectional study was conducted from January to September 2016 involving 303 patients with SSIs in obstetrics \& gynecology; and general surgery wards in three health facilities. Clinical-demographic characteristics of patients were obtained using structured questionnaires before surgery. Bacterial analysis of the air and floor of the theatre room was done using the standard culture method. Of the 303 patients enrolled with SSIs (median age 34 years), $71.6 \%$ were female, and $28.4 \%$ were males. Only $14.5 \%$ developed SSIs, with predominant isolates being Staphylococcus aureus $33.33 \%$ and Escherichia coli $24 \%$. The majority of recruited participants underwent a C-section of $58 \%$ and the least amputations of $0.3 \%$. Duration of operation or surgery, p-value 0.002 (95\% CI 1.599-7.667) was significantly associated with SSIs. Gram-negative bacteria were found resistant (50-100\%) to ampicillin, gentamycin, and ciprofloxacin, the commonly used post-operative drugs of choice. Hospital-acquired infections were common with emerging antibiotic-resistant strains isolated in most SSIs at Kasese hospitals. The development of resistance to commonly used antibiotics such as ampicillin, gentamycin, and ciprofloxacin than previously reported calls for laboratory-guided SSIs therapy and strengthening infection control policies.
\end{abstract}

Received: December 28th, 2020

Accepted: April 1st, 2021

Published: May 30th, 2021

(C) 2021 Abraham Bwalhuma Muhindo, Adamu Almustapha Aliero, Martin Odoki, Ibrahim Ntulume, Emmanuel Eilu, Joe Mutebi, Yap Boum II, Richard Onyuthi Apecu. Published by Institute for Research and Community Services Universitas Muhammadiyah Palangkaraya. This is an Open Access article under the CC-BY-SA License (http://creativecommons.org/licenses/by-sa/4.0/). DOI: https://doi.org/10.33084/bjop.v4i2.1948

\section{INTRODUCTION}

Nosocomial infection (NI), also called "hospital-acquired infection (HAI) or healthcare-associated infection
(HCAI)," is an infection acquired in a hospital by a patient who was admitted for a reason other than that infection ${ }^{1,2}$. It is also an infection(s) occurring in a patient in a hospital or other health care facility in whom the infection was not 
present or incubating at the time of admission ${ }^{3}$. These infections occur up to 48 hours after hospital admission, or three days after discharge, to 30 days after the operation. Despite progress in public health and hospital care, infections continue to develop in hospitalized patients and may also affect hospital staff4.

Globally, 2 million people are affected by nosocomial infections each year, and about $20 \%$ of them result in hospitalization 5 . According to Azeez-Akande ${ }^{6}$, the proportions of nosocomial staphylococcal infection range from $2-50 \%$ in Sub-Saharan Africa and speckled with the setting, with intensive care units (ICUs) having the highest incidence rates of 21.2-35.6\%. In Uganda, like other African regions, there is no comprehensive data to show the magnitude of nosocomial infection in the country. Individual research from across the country indicates a contentious rise of nosocomial infections with resistance among the bacteria species isolated 7 . For example, A study by Seni et al. ${ }^{8}$ in Mulago National Referral Hospital, Uganda, found that about $10 \%$ of patients undergoing surgical procedures become septic. Similarly, Adam et al..$^{5}$ reported $30.8 \%$ strains of $S$. epidermidis isolated from 363 environmental samples from wards surfaces of Kampala International University-Teaching Hospital (KIU-TH). Among these isolates, 11 (9.8\%) were found resistant to cefoxitin.

Many factors flues this infection among hospitalized patients: decreased immunity among patients, increasing variety of medical procedures, invasive techniques are creating potential routes of infection, and transmission of drug-resistant bacteria among crowded hospital populations, in which poor infection control practices may facilitate transmission. Nosocomial infections lead to a prolonged hospital stay, long-term disability, increased antimicrobial resistance, increased socio-economic disturbance, and increased mortality rate re, $^{1,29}$.
Hospitals have become particularly notorious for spreading lethal infections; in each hundred hospitalized patients, seven in developed and ten in developing countries may acquire $\mathrm{HCAI}^{1,10}$. Furthermore, most of the pathogens causing HAI developed resistance to the most commonly prescribed antibiotics in healthcare settings, making it difficult for health care providers to deliver effective health care services. Due to that, World Health Organization recommended urgent action to prevent and control the spread of antibiotic-resistant microorganisms in health care settings which involved researching to adapt and validate surveillance protocols based on the reality of developing countries, researching the potential involvement of patients and their families in HAI reporting and control, among the others ${ }^{2,11}$. Literature has shown that the HAI burden was more in poor-income countries, and there lacked comprehensive data on the magnitude of the infections in the region ${ }^{12-14}$. Therefore, this study was aimed at determining the prevalence of nosocomial infections and antibiotic susceptibility profiles of bacteria isolated from Kasese District Hospitals in Western Uganda.

\section{MATERIALS AND METHODS}

\section{Materials}

The materials used include Nutrient agar/NA, MacConkey agar/MAC, Chocolate agar/CHOC, Mueller-Hinton agar/MHA (Oxoid), 0.5 McFarland standard, antibiotics discs of penicillin, erythromycin, oxacillin, ampicillin, tetracycline, ciprofloxacin, clindamycin, chloramphenicol, cefuroxime, ceftriaxone, ceftazidime, gentamycin, and cotrimoxazole. The main instruments used in this study were incubator, $\mathrm{API} 囚 20 \mathrm{E}$ V4.1 and API®staph V4:1 kit (bioMérieux, France). The software used for data analysis was IBM SPSS Statistics ®16.0. 


\section{Methods}

\section{Study design and sites}

The study was a descriptive cross-sectional laboratorybased study. The study was carried out in Kasese District Western Uganda, located on latitude and longitude $\left(0.1699^{\circ} \mathrm{N}, 30.0781^{\circ} \mathrm{E}\right)$ with a population of 738,300 . Three health facilities: a private, not-for-profit health facility and also a Teaching Hospital (Kagando Hospital), one government hospital (Bwera Hospital), and a private forprofit health facility (Bishop Masereka Medical Center) which a nongovernmental organization owns were studied. These health facilities were spread out and gave a good impression and representation of all facilities in Kasese District with a bed size of not less than 30 and with regular surgical operations (Figure 1). Furthermore, these hospitals were chosen as the study sites because they were primary health care providers for both out-patients and in-patients in the district. Patients that were newly admitted and slated for operations were recruited for the study following consent. Consenting participants were then monitored from the day of admission to the time the operation was performed. Non-consenting surgical and Cesarean section (C-section) patients and a patient who was terminally ill within selected hospitals were excluded from the study.

\section{Sample size determination}

A non-probability convenient sampling technique was used to achieve the predetermined sample size ${ }^{15}$. Samples size (both surgical and C-section patients) with a cumulative incidence of surgical site infection (SSIs) $10 \%$ among surgical patients in general and $9.4 \%$ among women who undergo C-section in Uganda at a national referral hospital ${ }^{16}$, as shown in Formula 1.

$$
\mathrm{n}=z^{2} p \frac{(1-p)}{d^{2}} \ldots[1]
$$

$\mathrm{z}=$ confidence limits at $95 \%$ confidence interval; $\mathrm{p}=$ rough estimate of the affected persons $(10) ;(1-p)$ = percentage of persons not affected; $d=$ absolute sampling error that can be tolerated $\pm 0.1 ; \mathrm{n}=$ estimated sample size.
Therefore, the minimum sample size required according to Formula 1 was shown in the following calculations:

$$
\begin{gathered}
n=1.96^{2} x 0.01 \frac{(1-0.10)}{0.1^{2}} \\
n=345
\end{gathered}
$$

Only three of the initial four health facilities proposed permitted the study, and of the 345 initial participants proposed, 303 participants were enrolled from the three study sites.

\section{Bacterial analysis of the operation theater air and floor}

Bacterial loads of the air in the operation theatres of all the selected facilities were studied by the plate settling method $^{17}$. Open plates of NA, MAC, and CHOC were placed in different areas of the theatre at the start of each operation and left open until the operation was completed. All plates were closed and then incubated at $37^{\circ} \mathrm{C}$ for 24 hours aerobically for NA and MAC, while CHOC was incubated in a jar containing $10 \% \mathrm{CO}_{2}$ for 24 hours. Colonies were counted and converted to colonyforming units per cubic meter $\left(\mathrm{CFU} / \mathrm{m}^{3}\right)$.

About $1 \mathrm{~m}^{2}$ of theatre floor subdivided into squares was randomly swabbed to estimate the bacterial loads of the theatre floor. Moistened swabs were dispensed in $9 \mathrm{~mL}$ of normal saline and mixed well. As much as $1 \mathrm{~mL}$ of each mixture was inoculated on NA, MAC, and $\mathrm{CHOC}$ plates. The plates of NA and MAC have incubated aerobically at $37^{\circ} \mathrm{C}$, while CHOC plates were incubated in a jar containing $10 \% \mathrm{CO}_{2}$ for 24 hours ${ }^{18}$. Colonies were counted and converted to colony-forming units per square meter $\left(\mathrm{CFU} / \mathrm{m}^{2}\right)$.

\section{Detection of surgical site nosocomial infections}

Operated patients in the ward were followed daily, and operations sites were inspected for signs of infection. Patients' notes were also checked for information that indicates signs of SSIs. The classification of an operation site as positive for SSIs was based on the Centers for Disease Control and Prevention (CDC) definition, which 
states that "SSI is an infection that occurred within 30 days after operative procedure"19. The patient would have developed SSIs when at least one of the following was noticed: purulent discharge from the superficial incision; isolated organism from an aseptically obtained culture of fluid or tissue from the superficial surgical incision; and signs or symptoms of infection pain, tenderness, or heat and superficial incision deliberately opened by the surgeon unless the incision was culture negative. For any occurrence of the above signs or symptoms on a patient, consultant attention would be drawn and a decision on the status of the sign made. These sites were swabbed using sterile cotton swabs and inoculated in $9 \mathrm{~mL}$ sterile peptone water broths, inoculated on NA, MAC, and CHOC, and incubated at $37^{\circ} \mathrm{C}$ for 24 hours.

\section{Characterization of bacterial isolates}

All the isolates sub-cultured onto NA slants were characterized by their cultural, morphological, and biochemical reactions ${ }^{19}$. Bacterial species were also confirmed using API®20E V4.1 and API®staph V4:1. A $0.5 \mathrm{McF}$ arland standard suspension of each bacterial isolates was prepared and each identification strip inoculated by pipetting the suspension into each cupule as instructed by the manufacturer. This was then incubated at $35-37^{\circ} \mathrm{C}$ in the moist chamber for 24 hours. After 24 hours incubation period, reagents were added to the appropriate well, and the reaction of each cupule was read by comparing the color of each well to the reading table in the package insert. Identity of the bacterial isolates was obtained by use of profiles for this combination of reactions from API web using $\mathrm{API} \circledast 20 \mathrm{E}$ V4.1 and $\mathrm{API}$ staph V4:120.

\section{Antibiotics susceptibility profiles of the isolates}

Antimicrobial susceptibility testing was done using the disk diffusion method using MHA according to the method described by the Clinical and Laboratory
Standards Institute (CLSI) guidelines ${ }^{21}$. A susceptibility test was done using the stokes method. Both the standard controls and the test organism were inoculated on the same plate, and the zone of inhibition of the test organism was compared directly with that of the control ${ }^{22}$. Antibiotics discs used were penicillin (10 $\mu g)$, erythromycin $(15 \mu \mathrm{g})$, oxacillin (1 $\mu \mathrm{g})$, ampicillin (10 $\mu \mathrm{g})$, tetracycline $(30 \mu \mathrm{g})$, ciprofloxacin $(5 \mu \mathrm{g})$, clindamycin (2 $\mu \mathrm{g})$, chloramphenicol (30 $\mu \mathrm{g})$, cefuroxime (30 $\mu \mathrm{g})$, ceftriaxone $(30 \mu \mathrm{g})$, ceftazidime $(30 \mu \mathrm{g})$, gentamycin $(10$ $\mu \mathrm{g})$, and cotrimoxazole(1.25/23.75 $\mu \mathrm{g})$. After 24 and 48 hours of incubation at $37^{\circ} \mathrm{C}$, all plates were read and results interpreted according to the standard procedure of CLSI.

Determination of multiple antibiotics resistance index

The multiple antibiotic resistance (MAR) index was determined for each of the selected bacterial isolates by dividing the number of antibiotics to which the isolate was resistant by the total number of antibiotics tested ${ }^{23}$.

\section{Data analysis}

Data collected through a questionnaire and from sample analysis were entered in Microsoft Excel data set. The data set was imported into SPSS 16.0 for analysis and presented using tables and bar graphs. Means, proportions, and medians were used to characterize the study participants ${ }^{24}$.

\section{Ethical considerations}

The ethical approval of the study was sought from Mbarara University of Science and Technology, Faculty of Medicine Research Committee (Ref: DMS6); Mbarara University of Science and Technology, Institutional Research and Ethics Committee (IREC) on Human Research (Ref: MUREC1/7); and final approval were obtained from all the three studied Hospitals. All research protocols were performed by the ethical standards of committees on human experimentation laid down in the Declaration of Helsinki. 


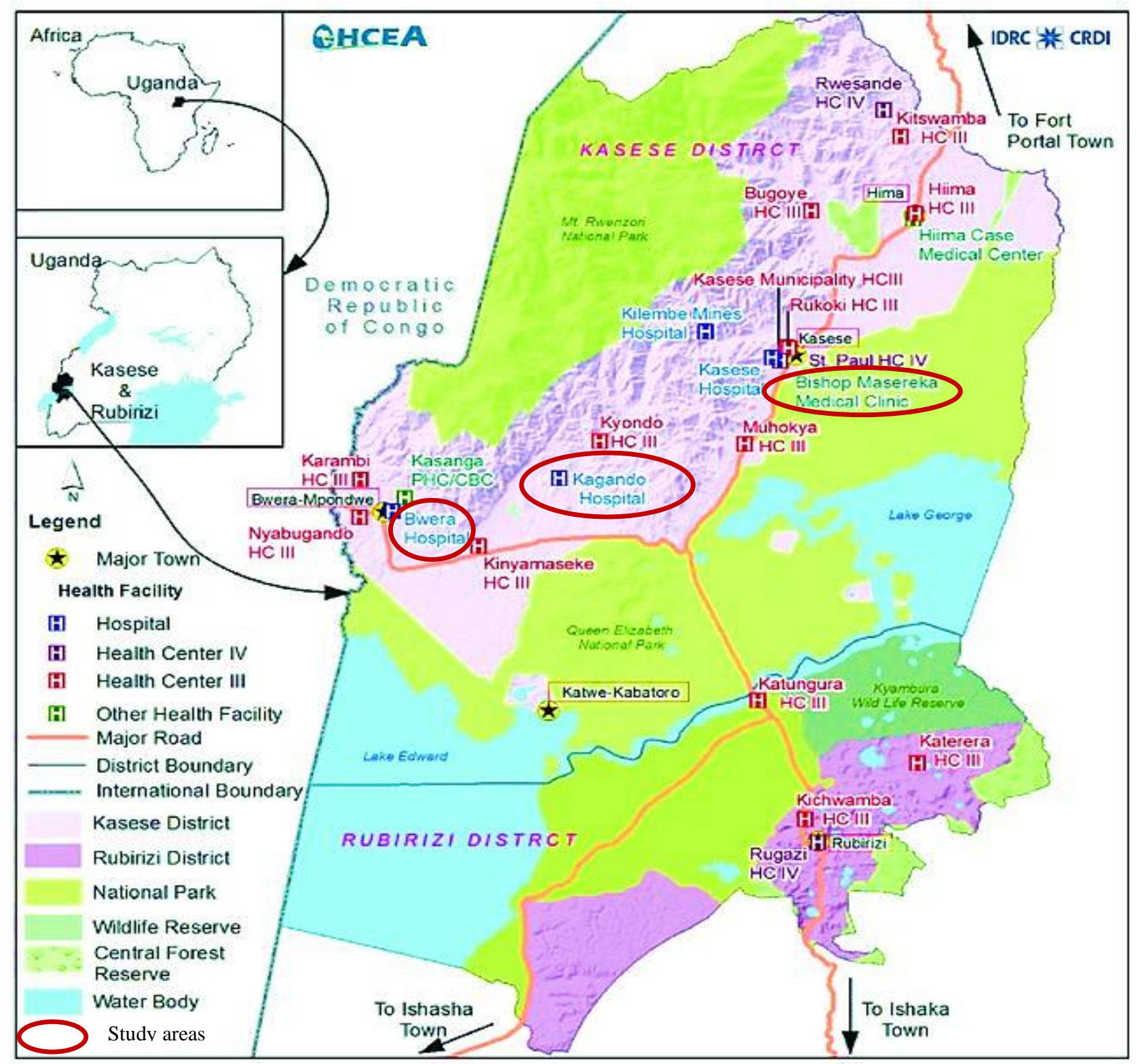

Figure 1. Map of Kasese District, Uganda showing the distribution of health facilities

\section{RESULTS AND DISCUSSION}

Demographic characteristic of studied participants

As many as 303 patients from three selected health care facilities from Kasese District were enrolled in this study, 44SSIs were confirmed. As many as $71.6 \%$ of participants were females. Surgical site infection was more prevalent in males $17.4 \%$, patients who underwent explorative laparotomies 21.9\%, and those with American Society of Anesthesiologists (ASA) score of $321.1 \%$, as shown in Table I. The higher prevalence of SSIs found in males than their counterparts (female) was contrary to the findings of Nair et al.25, who reported a nearly equal prevalence ofSSIs from a tertiary hospital in the Northern Cape Province, South Africa.

Prevalence of surgical site infections in selected hospitals

Prevalence of nosocomial infection among hospitalized surgical and C-section patients among the hospitals studied was $20.9 \%, 12.2 \%$, and $8.6 \%$ for Bwera, Kagando, and Bishop Masereka Hospitals, respectively (Table II). These results were in line with Yallew et al. ${ }^{26}$ and Okello et al. ${ }^{27}$, who reported $14.9 \%(\mathrm{n}=908)$ and $14.0 \%(\mathrm{n}=129)$ 
prevalence of HAI from two teaching hospitals of the Amhara region in Ethiopia and large hospital in Northern Uganda, respectively. However, Nair et al. ${ }^{25}$ reported a lower prevalence of $7.67 \%(n=326)$ of HAI from a tertiary hospital in the Northern Cape Province, South Africa. The prevalence of nosocomial infection found in this study was lower compared to the prevalence reported by Greco et al. ${ }^{14}$ and Kesah et al. ${ }^{28}$, who reported an overall prevalence HAI of $45.8 \%$ ( $n=$ $664)$ and $28 \%(n=410)$ from Paediatric surgical patients at a tertiary health institution in Lagos, Nigeria and Larco Hospital Northwestern Uganda, respectively.

\section{Bacterial loads of air and floor}

Bacterial contamination was noted in all the three health facilities but notably highest in Bwera Hospital operating theatre with $600 \mathrm{CFU} / \mathrm{m}^{2}$ and $>60 \mathrm{CFU} / \mathrm{m}^{3}$ for floor and air, respectively (Figure 2).

Table I. Demographic characteristics of the studied participants

\begin{tabular}{lcc}
\hline \multicolumn{1}{c}{$\begin{array}{c}\text { Characteristics } \\
\mathbf{n}=\mathbf{3 0 3}\end{array}$} & $\begin{array}{c}\text { Proportion } \\
\mathbf{n}(\%)\end{array}$ & $\begin{array}{c}\text { SSIs } \\
\mathbf{n}(\%)\end{array}$ \\
\hline Hospital & & \\
\hline Kagando & $123(40.6)$ & $15(12.2)$ \\
Bwera & $110(36.3)$ & $23(20.9)$ \\
Bishop Masereka & $70(23.1)$ & $6(8.6)$ \\
\hline Gender and age & & \\
\hline Male & $86(28.4)$ & $15(17.4)$ \\
Female & $217(71.6)$ & $29(13.4)$ \\
Median age & 34 & - \\
\hline ASA score & & \\
\hline 1 & $11(3.6)$ & $2(18.2)$ \\
2 & $234(77.2)$ & $30(12.8$ \\
3 & $57(18.9)$ & $12(21.1)$ \\
4 & $1(0.3)$ & $0(0)$ \\
\hline Procedure & & \\
\hline C-section & $178(58.8)$ & $24(13.5)$ \\
Amputation & $1(0.3)$ & $1(3)$ \\
Hysterectomy & $3(0.99)$ & $0(0)$ \\
Prostatectomy & $13(4.29)$ & $1(7.7)$ \\
Herniorrhaphy & $6(1.98)$ & $1(16.7)$ \\
Appendectomy & $16(5.28)$ & $1(6.2)$ \\
Exploratory laparotomy & $73(24.09)$ & $16(21.9)$ \\
Vesicovaginal fistulas & $13(4.29)$ & $0(0)$ \\
\hline Time taken in surgery (minutes) & & \\
\hline$<31$ & $20(6.6)$ & $3(15)$ \\
31-60 & $231(76.24)$ & $27(11.7)$ \\
$>60$ & $52(17.16)$ & $14(26.9)$ \\
Mean duration of & 48 & - \\
procedure & & - \\
\hline Overall SSIs & & \\
\hline Yes & $44(14.5)$ & - \\
No & $259(85.5)$ & \\
\hline & & \\
\hline & & \\
\hline
\end{tabular}

The results also showed that the floor has the highest contaminant or bacterial loads compare to air from all the studied hospitals. The results of these findings were lower compared to the findings of Tang and Wan ${ }^{29}$. They reported higher mean and standard deviation of bacterial loads of 383.5 (2.1), 106.9 (2.0), 373.7 (1.6), 141.5 (2.2), 270.8 (1.8), 182.2 (1.8), 92.0 (2.3), 144.5 (2.0), and 87.19 (1.9) $\mathrm{CFU} / \mathrm{m}^{3}$ from air rooms of the post-operative recovery room, instrument room, supply washing room, delivery room, kidney transplant room, traumatic surgery room, and liver transplant room respectively in a Medical Center in Taiwan.

Table II. Prevalence of SSIs in the three selected hospitals of Kasese District, Western Uganda

\begin{tabular}{lcccc}
\hline \multicolumn{1}{c}{ Hospital } & $\begin{array}{c}\text { Samples } \\
\text { collected }\end{array}$ & $\begin{array}{c}\text { SSIs } \\
\mathbf{n}(\mathbf{\%})\end{array}$ & $\begin{array}{c}\text { Negative } \\
\mathbf{n ~ ( \% )}\end{array}$ & $\begin{array}{c}\text { Total } \\
\mathbf{n}(\%)\end{array}$ \\
\hline Kagando & 123 & 15 & 108 & 123 \\
Hospital & & $(12.2)$ & $(87.8)$ & $(100)$ \\
Bwera Hospital & 110 & 23 & 87 & 110 \\
& & $(20.9)$ & $(79.1)$ & $(100)$ \\
Bishop Masereka & 70 & 6 & 64 & 70 \\
Hospital & & $(8.6)$ & $(91.4)$ & $(100)$ \\
\hline
\end{tabular}

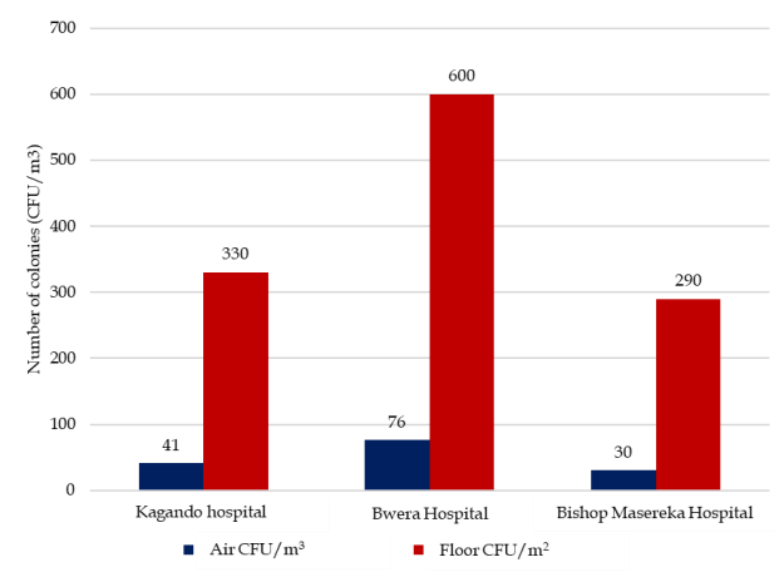

Figure 2. Comparison of bacterial loads on air and floor of operating theaters in three selected hospitals

\section{Contaminants isolated from air and floor of operating theatres} Coagulase-negative Staphylococci (CoNS), E. coli, and Micrococcus spp were the major contaminants isolated from air and floor in the operating theatre from the three studied hospitals, as shown in Table III. These organisms were reported to be a significant cause of nosocomial infections Onwubiko et $a l . .^{30}$, especially 
among immunocompromised patients. The results of contaminants bacterial isolates found in this study were in line with findings of 11 who reported a higher prevalence of CoNS from the air and protective wears in the operating theatre and surgical wards of two tertiary hospitals in Kano, Northwestern Nigeria. This result was contrary to the finding of Genet et al.31, who reported a higher prevalence of S. aureus $(70.8 \%)$, which was coagulase-positive from operating rooms and surgical wards at Jimma University Specialized Hospital, Southwest Ethiopia. However, Najotra et al. ${ }^{18}$ reported Bacillus spp as the most isolated bacterial species (87.6\%) from operation theatres of a tertiary care hospital in North India.

Table III. Isolated bacteria from air/floor of operating theatres in selected hospitals of Kasese District

\begin{tabular}{|c|c|c|c|c|c|c|c|}
\hline \multirow[b]{2}{*}{ 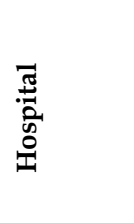 } & \multirow[b]{2}{*}{ 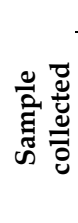 } & \multicolumn{6}{|c|}{ Isolated bacteria } \\
\hline & & $\begin{array}{l}0 \\
\vdots \\
0 \\
z \\
0 \\
0\end{array}$ & 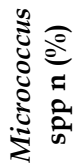 & 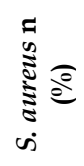 & 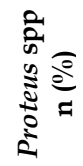 & 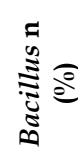 & 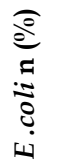 \\
\hline Bwera & 10 & 6 & 4 & 4 & 5 & 4 & 5 \\
\hline Hospital & & (60) & (40) & $(40)$ & (50) & $(40)$ & $(50)$ \\
\hline Kagando & 10 & 5 & 4 & 3 & 3 & 2 & 4 \\
\hline Hospital & & (50) & (40) & (30) & (30) & (20) & $(40)$ \\
\hline Bishop & 10 & 2 & 3 & 1 & 2 & 1 & 2 \\
\hline Masereka & & (20) & (30) & (10) & (20) & (10) & (20) \\
\hline Hospital & & & & & & & \\
\hline
\end{tabular}

\section{Isolated nosocomial surgical site pathogens}

Staphylococcus aureus (33\%) was the most Gram-positive bacteria isolated, whereas E. coli $(24 \%)$ was the most common Gram-negative nosocomial microorganism, as shown in Figure 3. The prevalence of $S$. aureus found in this study was higher than the finding of Agaba et al.12, who reported $4.40 \%$ and $4.48 \%$ from blood and tracheal samples collected from patients in Ugandan intensive care units (ICUs). This result was lower than Al Laham's findings ${ }^{32}$, who reported Staphylococcus spp $45.31 \%$ prevalence from general operating theatres in selected hospitals in the Gaza Strip, Palestine. This study also showed that $S$. aureus was the predominant species of
Gram-positive bacteria isolated from studied hospitals. This result was in line with the findings of Agaba et al. ${ }^{12}$, who also reported $S$. aureus as the commonest Grampositive bacteria isolated from Ugandan ICUs.

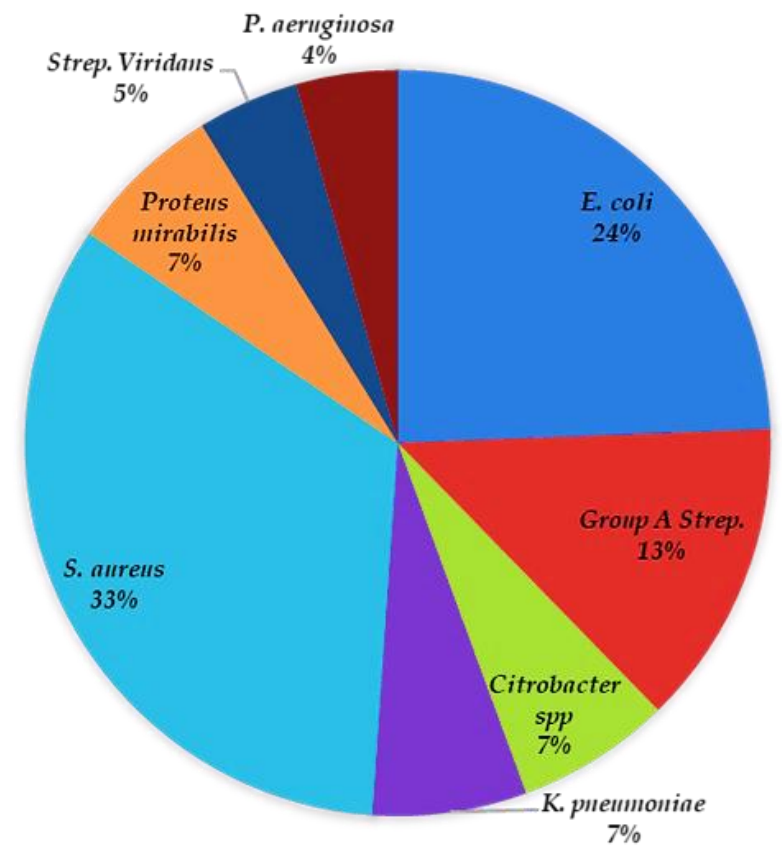

Figure 3. Frequency of nosocomial pathogenic bacteria isolated from three selected hospitals in the Kasese District of West Uganda

Susceptibility profiles of Gram-positive bacteria from surgical site

The results of this study showed that there was exceptional resistance of $S$. aureus to gentamycin (50\%), oxacillin (33\%), and resistance to clindamycin $(16 \%)$, with $100 \%$ sensitivity of Group A Streptococcus to erythromycin, ceftriaxone, and clindamycin, as presented in Table IV. This result was in line with the finding of Agaba et al. ${ }^{12}$, who reported that S. aureus isolated from Ugandan ICUs was resistant to erythromycin, penicillin, and oxacillin but susceptible to gentamycin. These findings also prove that different Gram-positive bacteria from different environments may have different antibiotic susceptibility profiles, regardless of the species ${ }^{33}$. 
Table IV. Susceptibility profiles of Gram-positive nosocomial SSI from three studied hospitals of Kasese District, Western Uganda

\begin{tabular}{|c|c|c|c|c|}
\hline Antibiotics $(\mu \mathrm{g})$ & DST & $\begin{array}{c}S . \\
\text { aureus } \\
\mathrm{n}=15 \\
(\%)\end{array}$ & $\begin{array}{c}S . \\
\text { viridans } \\
\mathrm{n}=2(\%)\end{array}$ & $\begin{array}{c}\text { Group } \\
\text { A Strep } \\
\mathbf{n}=6 \\
(\%)\end{array}$ \\
\hline \multirow[t]{3}{*}{ Ceftriaxone (30) } & $S$ & $\mathrm{n} / \mathrm{a}$ & $\mathrm{n} / \mathrm{a}$ & $2(33.3)$ \\
\hline & I & $\mathrm{n} / \mathrm{a}$ & $\mathrm{n} / \mathrm{a}$ & 0 \\
\hline & $\mathrm{R}$ & $\mathrm{n} / \mathrm{a}$ & $\mathrm{n} / \mathrm{a}$ & 0 \\
\hline Chloramphenicol & $S$ & 0 & $\mathrm{n} / \mathrm{a}$ & $4(66.7)$ \\
\hline \multirow[t]{2}{*}{$(30)$} & I & 0 & $\mathrm{n} / \mathrm{a}$ & 0 \\
\hline & $\mathrm{R}$ & $15(100)$ & $\mathrm{n} / \mathrm{a}$ & $2(33.3)$ \\
\hline \multirow[t]{3}{*}{ Ciprofloxacin (5) } & $S$ & $3(20)$ & $\mathrm{n} / \mathrm{a}$ & $\mathrm{n} / \mathrm{a}$ \\
\hline & I & 0 & $\mathrm{n} / \mathrm{a}$ & $\mathrm{n} / \mathrm{a}$ \\
\hline & $\mathrm{R}$ & $5(33.3)$ & $\mathrm{n} / \mathrm{a}$ & $\mathrm{n} / \mathrm{a}$ \\
\hline \multirow[t]{3}{*}{ Clindamycin (30) } & $S$ & $5(33.3)$ & $\mathrm{n} / \mathrm{a}$ & $2(33.3)$ \\
\hline & I & 0 & $\mathrm{n} / \mathrm{a}$ & 0 \\
\hline & $\mathrm{R}$ & $1(6.7)$ & $\mathrm{n} / \mathrm{a}$ & 0 \\
\hline Erythromycin & $S$ & $1(6.7)$ & $1(50)$ & $6(100)$ \\
\hline \multirow[t]{2}{*}{$(15)$} & I & 0 & 0 & 0 \\
\hline & $\mathrm{R}$ & $14(93.3)$ & $1(50)$ & 0 \\
\hline \multirow[t]{3}{*}{ Gentamycin (10) } & $S$ & $8(53.3)$ & $\mathrm{n} / \mathrm{a}$ & $\mathrm{n} / \mathrm{a}$ \\
\hline & I & 0 & $\mathrm{n} / \mathrm{a}$ & $\mathrm{n} / \mathrm{a}$ \\
\hline & $\mathrm{R}$ & 7 (46.6) & $\mathrm{n} / \mathrm{a}$ & $\mathrm{n} / \mathrm{a}$ \\
\hline \multirow[t]{3}{*}{ Oxacillin (1) } & $S$ & $8(53.3)$ & $\mathrm{n} / \mathrm{a}$ & $\mathrm{n} / \mathrm{a}$ \\
\hline & I & 0 & $\mathrm{n} / \mathrm{a}$ & $\mathrm{n} / \mathrm{a}$ \\
\hline & $\mathrm{R}$ & $4(26.6)$ & $\mathrm{n} / \mathrm{a}$ & $\mathrm{n} / \mathrm{a}$ \\
\hline \multirow[t]{3}{*}{ Penicillin (10) } & $S$ & $1(6.7)$ & $1(50)$ & $4(66.7)$ \\
\hline & I & 0 & 0 & 0 \\
\hline & $\mathrm{R}$ & $12(80)$ & $1(50)$ & $1(33.3)$ \\
\hline Cotrimoxazole & S & $\mathrm{n} / \mathrm{a}$ & $\mathrm{n} / \mathrm{a}$ & 0 \\
\hline \multirow[t]{2}{*}{$(1.25 / 23.75)$} & I & $\mathrm{n} / \mathrm{a}$ & $\mathrm{n} / \mathrm{a}$ & 0 \\
\hline & $\mathrm{R}$ & $\mathrm{n} / \mathrm{a}$ & $\mathrm{n} / \mathrm{a}$ & $1(33.3)$ \\
\hline \multirow[t]{3}{*}{ Tetracycline (30) } & $S$ & $6(40)$ & 0 & $1(33.3)$ \\
\hline & I & 0 & 0 & 0 \\
\hline & $\mathrm{R}$ & $8(53.3)$ & $2(100)$ & $4(66.7)$ \\
\hline
\end{tabular}

DST: disc sensitivity testing; n/a: not tested; R: resistant; I: intermediate sensitivity; $S$ : sensitive

Susceptibility profiles of Gram-negative bacteria from surgical site

Gram-negative microorganisms showed 100\% resistance to ampicillin. There was $100 \%$ resistance to chloramphenicol by Proteus spp and Pseudomonas spp. Pseudomonas aeruginosa showed (50-100\%) sensitivity to gentamycin and ciprofloxacin, as presented in Table V. A 100\% resistance of all Gram-negative bacteria found in this study was contrary to Agaba et al.12, who reported lower resistance of Gram-negative bacteria isolated from Ugandan ICUs to ampicillin. This finding shows the need for regular antibiotics screening of these nosocomial pathogens to give correct antibiotic prescriptions in the healthcare facilities as recommended by the World Health Organization $(\mathrm{WHO})^{34}$.
Table V. Susceptibility profiles of Gram-negative nosocomial SSI from three studied hospitals of Kasese District, Western Uganda

\begin{tabular}{|c|c|c|c|c|c|c|c|}
\hline 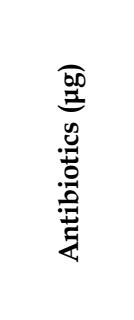 & 皆 & 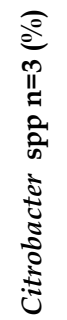 & 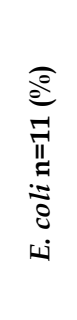 & 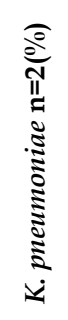 & 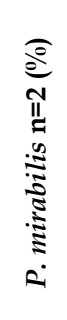 & 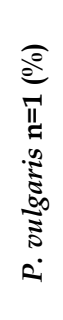 & 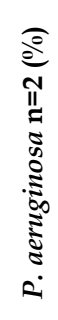 \\
\hline \multirow{4}{*}{$\begin{array}{l}\text { Ampi- } \\
\text { cillin (10) }\end{array}$} & $\mathrm{S}$ & 0 & 0 & 0 & 0 & 0 & 0 \\
\hline & I & 0 & 0 & 0 & 0 & 0 & 0 \\
\hline & $\mathrm{R}$ & 3 & 5 & 2 & 2 & 1 & 2 \\
\hline & & (100) & $(45.45)$ & (100) & (100) & (100) & (100) \\
\hline \multirow{3}{*}{$\begin{array}{l}\text { Ceftri- } \\
\text { axone } \\
(30)\end{array}$} & $\mathrm{S}$ & $\mathrm{n} / \mathrm{a}$ & 0 & $\mathrm{n} / \mathrm{a}$ & $\mathrm{n} / \mathrm{a}$ & $\mathrm{n} / \mathrm{a}$ & $\mathrm{n} / \mathrm{a}$ \\
\hline & I & $\mathrm{n} / \mathrm{a}$ & $\begin{array}{c}5 \\
(45.45)\end{array}$ & $\mathrm{n} / \mathrm{a}$ & $\mathrm{n} / \mathrm{a}$ & $\mathrm{n} / \mathrm{a}$ & $\mathrm{n} / \mathrm{a}$ \\
\hline & $\mathrm{R}$ & $\mathrm{n} / \mathrm{a}$ & $\begin{array}{c}5 \\
(45.45)\end{array}$ & $\mathrm{n} / \mathrm{a}$ & $\mathrm{n} / \mathrm{a}$ & $\mathrm{n} / \mathrm{a}$ & $\mathrm{n} / \mathrm{a}$ \\
\hline \multirow{3}{*}{$\begin{array}{l}\text { Cefta- } \\
\text { zidime } \\
(30)\end{array}$} & $\mathrm{S}$ & 0 & $\begin{array}{c}5 \\
(55.6)\end{array}$ & 0 & $1(50)$ & $\begin{array}{c}1 \\
(100)\end{array}$ & 0 \\
\hline & I & 0 & $\begin{array}{c}1 \\
(9.09)\end{array}$ & 0 & 0 & 0 & 0 \\
\hline & $\mathrm{R}$ & $\begin{array}{c}3 \\
(100)\end{array}$ & $\begin{array}{c}3 \\
(33.3)\end{array}$ & $\begin{array}{c}2 \\
(100)\end{array}$ & 0 & 0 & $\begin{array}{c}2 \\
(100)\end{array}$ \\
\hline \multirow{3}{*}{$\begin{array}{l}\text { Cefu- } \\
\text { roxime } \\
(30)\end{array}$} & $\mathrm{S}$ & 0 & $\begin{array}{c}2 \\
(18.2)\end{array}$ & $\mathrm{n} / \mathrm{a}$ & $1(50)$ & $\begin{array}{c}1 \\
(100)\end{array}$ & 0 \\
\hline & I & 0 & $\begin{array}{c}3 \\
(27.3)\end{array}$ & $\mathrm{n} / \mathrm{a}$ & 0 & 0 & 0 \\
\hline & $\mathrm{R}$ & $\begin{array}{c}3 \\
(100)\end{array}$ & $\begin{array}{c}6 \\
(54.6)\end{array}$ & $\mathrm{n} / \mathrm{a}$ & 0 & 0 & $\begin{array}{c}2 \\
(100)\end{array}$ \\
\hline \multirow{3}{*}{$\begin{array}{l}\text { Chloram- } \\
\text { phenicol } \\
(30)\end{array}$} & $\mathrm{S}$ & $\begin{array}{c}2 \\
(66.7)\end{array}$ & $\begin{array}{c}7 \\
(58.3)\end{array}$ & 0 & 0 & 0 & 0 \\
\hline & I & 0 & 0 & 0 & 0 & 0 & 0 \\
\hline & $\mathrm{R}$ & $\begin{array}{c}1 \\
(33.3)\end{array}$ & $\begin{array}{c}5 \\
(45.45)\end{array}$ & $1(50)$ & $\begin{array}{c}2 \\
(100)\end{array}$ & $\begin{array}{c}1 \\
(100)\end{array}$ & $\begin{array}{c}2 \\
(100)\end{array}$ \\
\hline \multirow{3}{*}{$\begin{array}{l}\text { Cipro- } \\
\text { floxacin } \\
\text { (5) }\end{array}$} & $\mathrm{S}$ & $\begin{array}{c}1 \\
(33.3)\end{array}$ & $\begin{array}{c}2 \\
(18.2)\end{array}$ & $\mathrm{n} / \mathrm{a}$ & $\mathrm{n} / \mathrm{a}$ & 0 & $\begin{array}{c}2 \\
(100)\end{array}$ \\
\hline & I & 0 & 0 & $\mathrm{n} / \mathrm{a}$ & $\mathrm{n} / \mathrm{a}$ & $\begin{array}{c}1 \\
(100)\end{array}$ & 0 \\
\hline & $\mathrm{R}$ & 0 & $\begin{array}{c}7 \\
(63.63)\end{array}$ & $\mathrm{n} / \mathrm{a}$ & $\mathrm{n} / \mathrm{a}$ & 0 & 0 \\
\hline \multirow{5}{*}{$\begin{array}{l}\text { Erythro- } \\
\text { mycin } \\
(15) \\
\text { Genta- } \\
\text { mycin } \\
(10)\end{array}$} & $\mathrm{S}$ & $\mathrm{n} / \mathrm{a}$ & $\mathrm{n} / \mathrm{a}$ & 0 & $\mathrm{n} / \mathrm{a}$ & $\mathrm{n} / \mathrm{a}$ & $\mathrm{n} / \mathrm{a}$ \\
\hline & $\begin{array}{l}\mathrm{I} \\
\mathrm{R}\end{array}$ & $\begin{array}{l}\mathrm{n} / \mathrm{a} \\
\mathrm{n} / \mathrm{a}\end{array}$ & $\begin{array}{l}\mathrm{n} / \mathrm{a} \\
\mathrm{n} / \mathrm{a}\end{array}$ & $\begin{array}{c}0 \\
1(50)\end{array}$ & $\begin{array}{l}\mathrm{n} / \mathrm{a} \\
\mathrm{n} / \mathrm{a}\end{array}$ & $\begin{array}{l}\mathrm{n} / \mathrm{a} \\
\mathrm{n} / \mathrm{a}\end{array}$ & $\begin{array}{l}\mathrm{n} / \mathrm{a} \\
\mathrm{n} / \mathrm{a}\end{array}$ \\
\hline & $S$ & $\begin{array}{c}1 \\
(33.3)\end{array}$ & $\begin{array}{c}5 \\
(45.45)\end{array}$ & 0 & $\begin{array}{c}2 \\
(100)\end{array}$ & $\begin{array}{c}1 \\
(100)\end{array}$ & $\begin{array}{c}2 \\
(100)\end{array}$ \\
\hline & I & $\begin{array}{c}1 \\
(33.3)\end{array}$ & 0 & 0 & 0 & 0 & 0 \\
\hline & $\mathrm{R}$ & 0 & $\begin{array}{c}5 \\
(45.45)\end{array}$ & $1(50)$ & 0 & 0 & 0 \\
\hline \multirow{6}{*}{$\begin{array}{l}\text { Cotri- } \\
\text { moxazole } \\
(1.25 / 23 . \\
75) \\
\text { Tetra- } \\
\text { cyclin }\end{array}$} & S & $\begin{array}{c}1 \\
(33.3)\end{array}$ & 0 & 0 & $\begin{array}{c}2 \\
(100)\end{array}$ & 0 & 0 \\
\hline & I & 0 & 0 & 0 & 0 & 0 & 0 \\
\hline & $\mathrm{R}$ & 0 & $\begin{array}{c}7 \\
(63.63)\end{array}$ & $1(50)$ & $2(50)$ & $\begin{array}{c}1 \\
(100)\end{array}$ & $\begin{array}{c}2 \\
(100)\end{array}$ \\
\hline & $\mathrm{S}$ & $\mathrm{n} / \mathrm{a}$ & $\begin{array}{c}2 \\
(18.2)\end{array}$ & $\mathrm{n} / \mathrm{a}$ & $\mathrm{n} / \mathrm{a}$ & $\mathrm{n} / \mathrm{a}$ & $\mathrm{n} / \mathrm{a}$ \\
\hline & I & $\mathrm{n} / \mathrm{a}$ & 0 & $\mathrm{n} / \mathrm{a}$ & $\mathrm{n} / \mathrm{a}$ & $\mathrm{n} / \mathrm{a}$ & $\mathrm{n} / \mathrm{a}$ \\
\hline & $\mathrm{R}$ & $\mathrm{n} / \mathrm{a}$ & 0 & $\mathrm{n} / \mathrm{a}$ & $\mathrm{n} / \mathrm{a}$ & $\mathrm{n} / \mathrm{a}$ & $\mathrm{n} / \mathrm{a}$ \\
\hline
\end{tabular}

DST: disc sensitivity testing; $\mathrm{n} / \mathrm{a}$ : not tested; R: resistant; I: intermediate sensitivity; $S$ : sensitive

\section{Multiple antibiotic resistance index of isolated bacteria}

The MAR index of the nosocomial pathogens isolated in selected hospitals at Kasese District Western Uganda was presented in Figure 4, and the results showed that all isolates were resistant to multiple antibiotics. However, those with the highest MAR index were K. pneumonia (1), E. coli (0.7), P. aeruginosa (0.7), and Citrobacter spp (0.6) 
among the Gram-negative bacteria. While S. aureus (0.8) and S. viridians (0.6) had the highest MAR index among the Gram-positive bacteria. The MAR index of $K$. pneumonia reported in this study was higher compared to Osundiya et al. ${ }^{24}$, who reported the MAR index of 0.4 for Klebsiella spp isolated in Lagos University Teaching Hospital, but in line with that reported by Stanley et al. 35 from the same location in Kasese District in Figure 1.

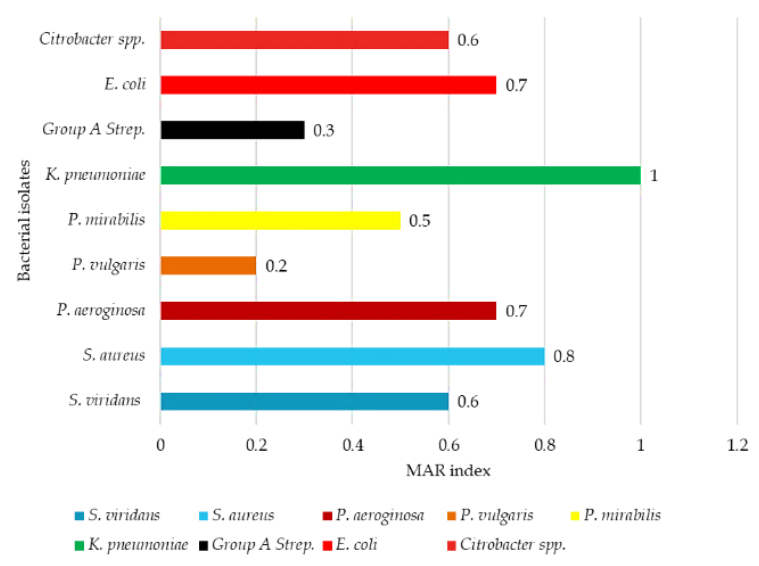

Figure 4. The MAR index of isolated nosocomial SSI pathogens

Bivariate analysis of risk factors for developing SSIs in Kasese District selected hospitals

In the bivariate analysis, the hospital attended in Kasese District Western Uganda and duration of procedure were significant risk factors for acquiring SSIs, with pvalues of 0.033 (CI 0.137-0.921) and 0.006 (CI 1.338-5.791), respectively (Table VI).

Multivariate analysis of risk factors for developing SSIs in Kasese District selected hospitals

The factors that had a p-value $<0.05$ in the bivariate analysis were included in the multivariate analysis. Binary logistic regression was done where the model showed an $8 \%$ variation independent variable (Nagelkerke's $\mathrm{R}^{2}$ 0.088). The model used in this analysis best fit data ( $p 0.819$ ) and $85.5 \%$ of the participants were correctly classified as being infected. The results of multivariate analysis showed that those who had 30-60 minutes surgery were 3.501 times more likely to have SSIs, and it was statistically significant with p 0.002, as shown in Table VII.

Table VI. Bivariate analysis between socio-demographic factors and SSIs

\begin{tabular}{|c|c|c|c|c|c|c|}
\hline$\frac{\stackrel{0}{\frac{0}{0}}}{\stackrel{\frac{\pi}{d}}{\frac{\pi}{7}}}$ & $\underset{a}{a}$ & 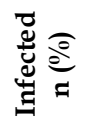 & 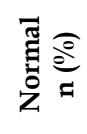 & 芑 & $\begin{array}{l}0 \\
\text { i̊ } \\
\text { in }\end{array}$ & $\begin{array}{l}\frac{0}{\Xi} \\
\frac{1}{2} \\
\dot{2} \\
\dot{2}\end{array}$ \\
\hline \multicolumn{7}{|c|}{ Hospitals } \\
\hline $\begin{array}{l}\text { Kagando } \\
\text { Hospital }\end{array}$ & $\begin{array}{c}123 \\
(100)\end{array}$ & $\begin{array}{c}15 \\
(12.5)\end{array}$ & $\begin{array}{c}108 \\
(87.8)\end{array}$ & 0.675 & $\begin{array}{c}0.249- \\
1.827\end{array}$ & 0.439 \\
\hline Bwera & 110 & 23 & 87 & 0.355 & $0.137-$ & $0.033^{*}$ \\
\hline Hospital & $(100)$ & $(20.9)$ & $(79.1)$ & & 0.921 & \\
\hline $\begin{array}{l}\text { Bishop } \\
\text { Masereka } \\
\text { Hospital }\end{array}$ & $\begin{array}{c}70 \\
(100)\end{array}$ & $6(8.6)$ & $64(64)$ & 1.000 & - & - \\
\hline \multicolumn{7}{|l|}{ Gender } \\
\hline Female & $\begin{array}{c}217 \\
(100)\end{array}$ & $\begin{array}{c}29 \\
(13.4)\end{array}$ & $\begin{array}{c}188 \\
(86.6)\end{array}$ & 1.370 & $\begin{array}{c}0.694- \\
2.705\end{array}$ & 0.365 \\
\hline Male & $\begin{array}{c}86 \\
(100) \\
\end{array}$ & $\begin{array}{c}15 \\
(17.4) \\
\end{array}$ & $\begin{array}{c}71 \\
(86.6) \\
\end{array}$ & 1.000 & & \\
\hline \multicolumn{7}{|c|}{ Duration of surgical procedure (minutes) } \\
\hline$<30$ & $\begin{array}{c}20 \\
(6.6)\end{array}$ & $\begin{array}{c}3 \\
(15.0)\end{array}$ & $\begin{array}{c}17 \\
(85.0)\end{array}$ & 2.088 & $\begin{array}{l}0.530- \\
8.231\end{array}$ & 0.293 \\
\hline $30-60$ & $\begin{array}{c}231 \\
(76.24)\end{array}$ & $\begin{array}{c}27 \\
(11.7)\end{array}$ & $\begin{array}{c}204 \\
(88.3)\end{array}$ & 2.784 & $\begin{array}{l}1.338- \\
5.791\end{array}$ & $0.006^{*}$ \\
\hline$>60$ & $\begin{array}{c}52 \\
(17.16) \\
\end{array}$ & $\begin{array}{c}14 \\
(26.9)\end{array}$ & $\begin{array}{c}38 \\
(73.1)\end{array}$ & 1.000 & - & - \\
\hline
\end{tabular}

*Statistically significant at $95 \%$ level of confidence

Table VII. Multivariate analysis between socio-demographic factors and SSIs

\begin{tabular}{|c|c|c|c|c|c|c|}
\hline$\frac{\stackrel{0}{\frac{0}{0}}}{\stackrel{\frac{\pi}{3}}{7}}$ & $\underbrace{a}_{a}$ & 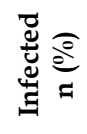 & 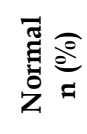 & 苞 & 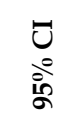 & $\begin{array}{l}\frac{0}{5} \\
\frac{\pi}{2} \\
\dot{2}\end{array}$ \\
\hline \multicolumn{7}{|c|}{ Hospitals } \\
\hline $\begin{array}{l}\text { Kagando } \\
\text { Hospital }\end{array}$ & $\begin{array}{c}123 \\
(100)\end{array}$ & $\begin{array}{c}15 \\
(12.5)\end{array}$ & $\begin{array}{c}108 \\
(87.8)\end{array}$ & 0.843 & $\begin{array}{c}0.299- \\
1.827\end{array}$ & 0.749 \\
\hline $\begin{array}{l}\text { Bwera } \\
\text { Hospital }\end{array}$ & $\begin{array}{c}110 \\
(100)\end{array}$ & $\begin{array}{c}23 \\
(20.9)\end{array}$ & $\begin{array}{c}87 \\
(79.1)\end{array}$ & 0.324 & $\begin{array}{c}0.122- \\
0.859\end{array}$ & $0.23^{*}$ \\
\hline $\begin{array}{l}\text { Bishop } \\
\text { Masereka } \\
\text { Hospital }\end{array}$ & $\begin{array}{c}70 \\
(100)\end{array}$ & $6(8.6)$ & $64(64)$ & 1.000 & - & - \\
\hline \multicolumn{7}{|c|}{ Duration of surgical procedure (minutes) } \\
\hline$<30$ & $\begin{array}{c}20 \\
(6.6)\end{array}$ & $\begin{array}{c}17 \\
(85.0)\end{array}$ & $\begin{array}{c}3 \\
(15.0)\end{array}$ & 1.875 & $\begin{array}{l}0.530- \\
8.231\end{array}$ & 0.38 \\
\hline $30-60$ & $\begin{array}{c}231 \\
(76.24)\end{array}$ & $\begin{array}{c}27 \\
(11.7)\end{array}$ & $\begin{array}{c}204 \\
(88.3)\end{array}$ & 2.784 & $\begin{array}{c}1.599- \\
7.667\end{array}$ & $0.002^{*}$ \\
\hline$>60$ & $\begin{array}{c}52 \\
(17.16) \\
\end{array}$ & $\begin{array}{c}14 \\
(26.9)\end{array}$ & $\begin{array}{c}38 \\
(73.1) \\
\end{array}$ & 1.000 & - & - \\
\hline
\end{tabular}

\section{CONCLUSION}

Based on the findings of this study, nosocomial infections in surgically hospitalized patients were found to be 20.9\%, 12.2\%, and 8.6\% for Bwera Hospital, Kagando Hospital, and Bishop Masereka Hospitals, respectively. Staphylococcus aureus and E. coli were found the most 
common bacteria isolated. Most of the isolates were found to be resistant to more than one antibiotic drug of choice.

\section{ACKNOWLEDGMENT}

The authors are grateful to laboratory technicians and staff of the Department of Microbiology, Mbarara University of Science and Technology, Uganda. We also acknowledge the hospital management of Kagando Teaching Hospital, Bwera Hospital, and Bishop Masereka Medical Centre for permitting us to collect samples. There was no external grand received to the study. All author contributes to financing this work.

\section{AUTHORS' CONTRIBUTION}

\section{Abraham Bwalhuma Muhindo and Richard Onyuthi}

Apecu funded and conducted laboratory work for this study. The first mentioned authors as well as Adamu Almustapha Aliero, Martin Odoki, Ibrahim Ntulume, Emmanuel Eilu, and Joe Mutebi contributed equally to conceptualization, data curation, formal analysis, project administration, resources, supervision, validation, visualization, writing - original draft, and writing review \& editing. All authors read and approved the final manuscript.

\section{DATA AVAILABILITY}

The tables and bar graphs in this research article contain the data that support the study conclusions.

\section{CONFLICT OF INTEREST}

The authors declare no conflict of interest.

\section{REFERENCES}

1. Haque M, Sartelli M, McKimm J, Abu Bakar M. Health care-associated infections - an overview.
Infect Drug Resist. 2018;11:2321-33. doi:10.2147/IDR.S177247

2. Khan HA, Baig FK, Mehboob R. Nosocomial infections: Epidemiology, prevention, control and surveillance. Asian Pac J Trop Biomed. 2017;7(5):47882. doi:10.1016/j.apjtb.2017.01.019

3. Voidazan S, Albu S, Toth R, Grigorescu B, Rachita A, Moldovan I. Healthcare Associated Infections-A New Pathology in Medical Practice? Int J Environ Res Public Health. 2020;17(3):760. doi:10.3390/ijerph17030760

4. Revelas A. Healthcare - associated infections: A public health problem. Niger Med J. 2012;53(2):59-64. doi:10.4103/0300-1652.103543

5. Adam AS, Micheni L, Onkoba SK, Ntulume I, Aliero AA, Namatovu A. Antibiotic Susceptibility Pattern and Detection of mecA Gene in Methicillin Resistant Staphylococcus Epidermidis Isolated from Wards Surfaces of Kampala International University Teaching Hospital, Uganda. Rom Arch Microbiol Immunol. 2020;79(1):24-36.

6. Azeez-Akande O. Emerging and re-emerging infectious agents of nosocomial diseases - The need for review of hospital policy and control strategies. Bayero J Pure Appl Sci. 2012;5(2):19-25. doi:10.4314/bajopas.v5i2.3

7. Ssekitoleko RT, OshabaheebwaS, Munabi IG, Tusabe MS, Namayega C, Ngabirano BA, et al. The role of medical equipment in the spread of nosocomial infections: a cross-sectional study in four tertiary public health facilities in Uganda. BMC Public Health. 2020;20(1):1561. doi:10.1186/s12889-02009662-w

8. Seni J, Najjuka CF, Kateete DP, Makobore P, Joloba $\mathrm{ML}$, Kajumbula $\mathrm{H}$, et al. Antimicrobial resistance in hospitalized surgical patients: a silently emerging public health concern in Uganda. BMC Res Notes. 2013;6:298. doi:10.1186/1756-0500-6-298

9. Tolera M, Marami D, Abate D, Dheresa M. Are Invasive Procedures and a Longer Hospital Stay Increasing the Risk of Healthcare-Associated Infections among the Admitted Patients at Hiwot Fana Specialized University Hospital, Eastern Ethiopia? Adv Prev Med. 2020;2020:6875463. doi:10.1155/2020/6875463

10. Danasekaran R, Mani G, Annadurai K. Prevention of healthcare-associated infections: protecting patients, 
saving lives. Int J Community Med Public Health. 2014;1(1):67-8. doi:10.5455/23946040.ijcmph20141114

11. Abadi ATB, Rizvanov AA, Haertlé T, Blatt TL. World Health Organization Report: Current Crisis of Antibiotic Resistance. BioNanoScience. 2019;9:778-88. doi:10.1007/s12668-019-00658-4

12. Agaba P, TumukundeJ, Tindimwebwa JVB, Kwizera A. Nosocomial bacterial infections and their antimicrobial susceptibility patterns among patients in Ugandan intensive care units: a cross sectional study. BMC Res Notes. 2017;10(1):349. doi:10.1186/s13104-017-2695-5

13. Wasswa P, Nalwadda CK, Buregyeya E, Gitta SN, Anguzu P, Nuwaha F. Implementation of infection control in health facilities in Arua district, Uganda: a cross-sectional study. BMC Infect Dis. 2015;15:268. doi:10.1186/s12879-015-0999-4

14. Greco D, Magombe I. Hospital acquired infections in a large north Ugandan hospital. J Prev Med Hyg. 2011;52(2):55-8.

15. Omair A. Sample size estimation and sampling techniques for selecting a representative sample. J Health Specialties. 2014;2(4):142-7. doi:10.4103/1658600X.142783

16. Hodges AM, Agaba S. Wound infection in a rural hospital: the benefit of a wound management protocol. Trop Doct. 1997;27(3):174-5. doi:10.1177/004947559702700321

17. Getachew H, Derbie A, Mekonnen D. Surfaces and Air Bacteriology of Selected Wards at a Referral Hospital, Northwest Ethiopia: A Cross-Sectional Study. Int J Microbiol. 2018;2018:6413179. doi:10.1155/2018/6413179

18. Najotra DK, Malhotra AS, Slathia P, Raina S, Dhar A. Microbiological Surveillance of Operation Theatres: Five Year Retrospective Analysis from a Tertiary Care Hospital in North India. Int J Appl Basic Med Res. 2017;7(3):165-8. doi:10.4103/ijabmr.ijabmr_281_16

19. Onyekwelu I, Yakkanti R, Protzer L, Pinkston CM, Tucker C, Seligson D. Surgical Wound Classification and Surgical Site Infections in the Orthopaedic Patient. J Am Acad Orthop Surg Glob Res Rev. 2017;1(3):e022. oi:10.5435/JAAOSGlobal-D-1700022
20. Iskender NA, Algur OF, Aksu Y, Saral A. Isolation, identification and characterization of biotechnologically important bacteria from microflora of Dryocosmus kuriphilus Yasumatsu (Hymenoptera: Cynipidae). Biotechnol Biotechnol Equip. 2017;31(3):505-10. doi:10.1080/13102818.2017.1294035

21. Balouri M, Sadiki M, Ibnsouda SK. Methods for in vitro evaluating antimicrobial activity: A review. J Pharm Anal. 2016;6(2):71-9. doi:10.1016/j.jpha.2015.11.005

22. Khan ZA, Siddiqui MF, Park S. Current and Emerging Methods of Antibiotic Susceptibility Testing. Diagnostics. 2019;9(2):49. doi:10.3390/diagnostics9020049

23. Ayandele AA, Oladipo EK, Oyebisi O, Kaka MO, Prevalence of Multi-Antibiotic Resistant Escherichia coli and Klebsiella species obtained from a Tertiary Medical Institution in Oyo State, Nigeria. Qatar Med J. 2020;2020(1):9. doi:10.5339/qmj.2020.9

24. Osundiya OO, Oladele RO, Oduyebo OO. Multiple Antibiotic Resistance (MAR) indices of Pseudomonas and Klebsiella species isolates in Lagos University Teaching Hospital. African J Clin Exp Microbiol. 2013;14(3):164-8. doi:10.4314/ajcem.v14i3.8

25. Nair A, Steinberg WJ, Habib T, Saeed H, Raubenheimer JE. Prevalence of healthcareassociated infection at a tertiary hospital in the Northern Cape Province, South Africa. S Afr Fam Pract. 2018;60(5):162-7. doi:10.1080/20786190.2018.1487211

26. Yallew WW, Kumie A, Yehuala FM. Point prevalence of hospital-acquired infections in two teaching hospitals of Amhara region in Ethiopia. Drug Healthe Patient Saf. 2016;8:71-6. doi:10.2147/dhps.s107344

27. Okello TR, Kansiime J, Odora J. Invasive procedures and Hospital Acquired Infection (HAI) in A large hospital in Northern Uganda. East Cent Afr J Surg. 2014;19(3):77-84.

28. Kesah CNF, Egri-Okwaji MTC, Iroha E, Odugbemi TO. Aerobic bacterial nosocomial infections in paediatric surgical patients at a tertiary health institution in Lagos, Nigeria. Niger Postgrad Med J. 2004;11(1):4-9.

29. Tang CS, Wan GH. Air quality monitoring of the post-operative recovery room and locations surrounding operating theaters in a medical center in 
Taiwan. PLoS One. 2013;8(4):e61093. doi:10.1371/journal.pone.0061093

30. Onwubiko NE, Ejike N, Onyinyechi NP. Microbial contamination of air and protective wears in the operating theatre and surgical wards of two tertiary hospitals in Kano, Northwestern Nigeria. Int J Infect Control. 2014;11(3):3. doi:10.3396/IJIC.v11i3.020.15

31. Genet C, Kibru G, Tsegaye W. Indoor Air Bacterial Load and Antibiotic Susceptibility Pattern of Isolates in Operating Rooms and Surgical Wards at Jimma University Specialized Hospital, Southwest Ethiopia. Ethiop J Health Sci. 2011;21(1):9-17. doi:10.4314/ejhs.v21i1.69039

32. Al Laham NA. Prevalence of bacterial contamination in general operating theaters in selected hospitals in the Gaza Strip, Palestine. J Infect Public Health. 2012;5(1):43-51. doi:10.1016/j.jiph.2011.10.006

33. Munita JM, Arias CA. Mechanisms of Antibiotic Resistance. Microbiol Spectr. 2016;4(2):1-24. doi:10.1128/microbiolspec.VMBF-0016-2015

34. Yimenu DK, Emam A, Elemineh E, Atalay W. Assessment of Antibiotic Prescribing Patterns at Outpatient Pharmacy Using World Health Organization Prescribing Indicators. I Prim Care Community Health. 2019;10: 2150132719886942. doi:10.1177/2150132719886942

35. Stanley IJ, Kajumbula H, Bazira J, Kansiime C, Rwego IB, Asiimwe BB. Multidrug resistance among Escherichia coli and Klebsiella pneumoniae carried in the gut of out-patients from pastoralist communities of Kasese district, Uganda. PLoS One. 2018;13(7):e0200093.

doi:10.1371/journal.pone.0200093 